\title{
COOPERATIVE CALIBRATION AND ANALYSIS OF CEMENT CLINKER PHASES
}

\section{Struble*}

U.S. DEPARTMENT OF COMMERCE Natlonal Institute of Standards and Technology Center for Bullding Technology Galthersburg, MD 20899

\section{H. Kanare}

Constructlon Technology Laboratorles, Inc. skokle, IL 60077

*Present address: University of IIInols Department of Clvll Englneering Urbana, IL 61801-2397

U.S. DEPARTMENT OF COMMERCE Robert A. Mosbacher, Secretary NATIONAL INSTITUTE OF STANDARDS AND TECHNOLOGY

Raymond G. Kammer, Acting DIrector

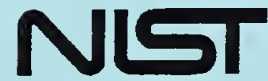




\section{COOPERATIVE CALIBRATION AND ANALYSIS OF CEMENT CLINKER PHASES}

\section{Struble*}

U.S. DEPARTMENT OF COMMERCE Natlonal Instltute of Standards and Technology Center for Bullding Technology Galthersburg, MD 20899

\section{H. Kanare}

Constructlon Technology Laboratorles, Inc. Skokle, IL 60077

*Present address: University of llilnols

Department of Clvil Engineering Urbana, IL 61801-2397

September 1989

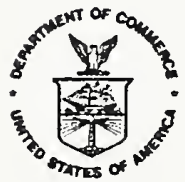

U.S. DEPARTMENT OF COMMERCE Robert A. Mosbacher, Secretary NATIONAL INSTITUTE OF STANDARDS AND TECHNOLOGY

Raymond G. Kammer, Acting Dlrector 

An interlaboratory calibration and analysis has been carried out by ASTM Task Group C01.23.01 to assess the use of quantitative $\mathrm{X}$-ray diffraction analysis to determine the proportion of phases in portland cement clinker. This interlaboratory test provides an estimate of precision and bias in the quantitative phase analysis of some clinker phases in mixtures prepared using calibrating phases. These estimates of precision and bias will be incorporated in a proposed standard test method on quantitative phase analysis of cement and clinker currently being developed by the task group. 
Page

ABSTRACT . . . . . . . . . . . . . . . . . . ii

1. INTRODUCTION . . . . . . . . . . . . . . . . . 1

2. PARTICIPANTS . . . . . . . . . . . . . . . 2

3. CAlibration Phases . . . . . . . . . . . . . . 2

3.1 Cubic $\mathrm{C}_{3} \mathrm{~A}$. . . . . . . . . . . . . . . . . 2

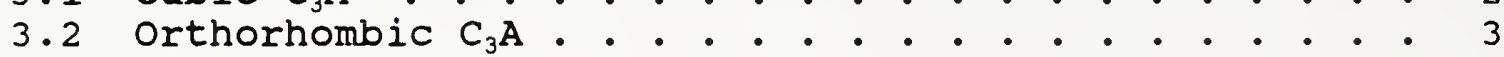

$3.3 \mathrm{MgO}$. . . . . . . . . . . . . . . . . . 3

$3.4 \mathrm{C}_{4} \mathrm{AF}$. . . . . . . . . . . . . . . . . 3

4. CALIBRATION MIXTURES . . . . . . . . . . . . 3

5. ANALYTICAL PROCEDURES . . . . . . . . . . . . . . 9

6. RESULTS ON UNKNOWN MIXTURES . . . . . . . . . . . . 11

7. CONCLUSIONS . . . . . . . . . . . . . . 18

8. ACKNOWLEDGEMENTS . . . . . . . . . . . . . 19 APPENDICES

Appendix 1. Laboratories Participating in Cooperative Calibration

Appendix 2. Summary of Results 21

Appendix 3. Statistical Analysis 32 
Page

Table 1. Calibration mixtures . . . . . . . . . . . . 6

Table 2. Proportions used in unknown mixtures . . . . . . 7

Table 3. Peaks recommended for QXRD analysis . . . . . . 10

Table 4. Summary of statistical analysis . . . . . . . . . 17

Table 3-1. QXRD results for statistical analysis . . . . . 36

Table 3-2. Cell averages . . . . . . . . . . • . . . 37

Table 3-3. Cell standard deviations . . . . . . . . . . 38

Table 3-4. Between-laboratory consistency statistic values . . . . . . . . . . . . . . 39

Table 3-5. Within-laboratory consistency statistic

values . . . . . . . . . . . . . . 40

Table 3-6. Summary of precision parameters . . . . . . . . 41

Table 3-7. Cell averages excluding Laboratory 3 . • • . . 42

Table 3-8. Summary of precision parameters excluding

Laboratory 3 . . . . . . . . . . . . . 43

Table 3-9. Linear regression, standard deviation

versus average ... . . . . . . . . . . . . 44 
Figure 1. Particle size distribution curve for cubic $\mathrm{C}_{3} \mathrm{~A}$ calibration phase . . . . . . . . . . . . 4

Figure 2. Particle size distribution curvé for Mgo calibration phase . . . . . . . . . . . . 5

Figure 3. Particle size distribution curve for calibration mixture No. 1 . . . . . . . . . . 8

Figure 4. Results from QXRD analysis of cubic $C_{3} A$ showing actual value for Unknown \#1 (lower line) and Unknown \#2 (upper line) . . . . . . .

Figure 5. Results from QXRD analysis of orthorhombic $C_{3} A$ showing actual value for Unknown \#1 (lower line) and Unknown \#2 (upper line) . . . .

Figure 6. Results from QXRD analysis of $C_{3} A$ (cubic plus orthorhombic) showing actual value for Unknown \#1 (lower 1 ine) and Unknown \#2 (upper line)

Figure 7. Results from QXRD analysis of $C_{4} A F$ showing actual value for Unknown \#1 (upper line) and Unknown \#2 (lower line) . . . . . . . . . .

Figure 8. Results from QXRD analysis of Mgo showing actual value for Unknown \#1 (upper line) and Unknown \#2 (lower line) . . . . . . . . . . . 16

Figure 3-1. Level of h-value for each laboratory (critical values indicated by upper and lower horizontal lines)

Figure 3-2. Level of $k$-value for each laboratory (critical value indicated by horizontal line)

Figure 3-3. Standard deviation versus average value (relative to the mixture) for each phase in each unknown mixture, showing results of linear regression analysis (Table 3-9) 
A proposed test method to determine the proportion of certain phases in portland cement or clinker using quantitative $X$-ray diffraction (QXRD) is currently under development by ASTM Task Group C01.23.01, chaired by Leslie Struble. The approach is similar to the approach used in developing performance requirements for rapid analytical methods for ASTM C 114 , Standard Methods for Chemical Analysis of Hydraulic Cement. The approach specifies certain general aspects of the analytical procedure, but leaves optional most of the specific details of the analysis. However, the approach specifies the levels of precision and bias that must be met for the particular selected analytical method to qualify. Detailed methods will be described that have been shown to meet these levels, including the methods used in the round-robin analyses to determine the specified precision and accuracy levels.

To develop the precision and bias levels for the test method, the task group is carrying out a number of interlaboratory analyses. These analyses utilize two groups of phases. The first group, tricalcium aluminate $\left(C_{3} A^{1}\right)$, tetracalcium aluminoferrite $\left(\mathrm{C}_{4} \mathrm{AF}\right)$, and magnesium oxide (MgO), are the subject of two interlaboratory analyses. The first, described in the present report, is a cooperative calibration using mixtures of individual phases prepared and made available by the construction Technology Laboratories (CTL). This cooperative calibration will be followed by a round-robin analysis of standard clinkers made available as Research Materials by the office of Standard Reference Materials (OSRM) of the National Institute of Standards and Technology (NIST).

\footnotetext{
${ }^{1}$ The following abbreviations (common in the cement and concrete literature) are used: $C$ for $\mathrm{CaO}, \mathrm{A}$ for $\mathrm{Al}_{2} \mathrm{O}_{3}, \mathrm{~F}$ for $\mathrm{Fe}_{2} \mathrm{O}_{3}$, and $\mathrm{S}$ for $\mathrm{SiO}_{2}$.
} 
The cooperative calibration included three mixtures in known proportions, to determine the relationship between the proportion of each phase and its XRD intensity, and two mixtures in unknown proportions. The results obtained for the two unknown mixtures in the cooperative calibration have been analyzed according to procedures in ASTM E 691, Standard Practice for conducting an Interlaboratory Test Program To Determine the Precision of Test Methods. Precision and bias levels determined from this statistical analysis will be incorporated subsequently in the test method.

The group of phases selected for this cooperative effort simulates the phases typically found in a salicylic acid or maleic acid extracted clinker. It is expected that the recommended analytical scheme in the test method will include two analyses: analysis before extraction for proportions of $C_{3} S$ and $\mathrm{C}_{2} \mathrm{~S}$, and analysis after extraction for proportions of $C_{3} A, C_{4} A F$, and $\mathrm{MgO}$.

\section{PARTICIPANTS}

Fifteen laboratories elected to participate in this effort. The participating laboratories are listed in Appendix 1. Nine laboratories have reported results. All results are reported anonymously (using a Laboratory Number). If additional results become available, this report will be amended.

\section{CALIBRATION PHASES}

Three phases were prepared at CTL for this calibration: cubic $C_{3} A$, orthorhombic $C_{3} A$ (stabilized by $N a$ ), $C_{4} A F$, and $M g o$. Each phase was prepared using reagent-grade chemicals.

\subsection{Cubic $\mathrm{C}_{3} \mathrm{~A}$}

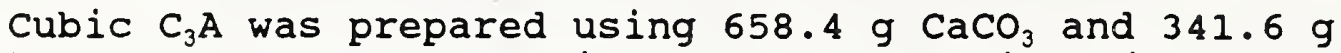
Al $(\mathrm{OH})_{3}$. These were ground in a 4-L pebble mill with $500 \mathrm{~mL}$ distilled water for $20 \mathrm{~min}$. The ball charge consisted of a 50:50 mixture of $9.5 \mathrm{~mm}(3 / 8 ")$ and $19.1 \mathrm{~mm}(3 / 4 ")$ aluminum oxide balls. The slurry was dried in a forced air oven. The dried powder mixture was pressed into pellets $52 \mathrm{~mm}$ diameter under approximately $7,000 \mathrm{~kg}$ (total load). The pellets were placed in platinum dishes and sintered by heating at $1450^{\circ} \mathrm{C}$ for 3 hrs. The sintered mass was crushed to pass a $0.60 \mathrm{~mm}$ (No. 30) sieve, then ground dry in a pebble mill for $60 \mathrm{~min}$. It was repelletized, reheated at $1450^{\circ} \mathrm{C}$ for $3 \mathrm{hrs}$, and ground in a pebble mill to a Blaine fineness of $3050 \mathrm{~cm}^{2} / \mathrm{g}$. Particle size analysis using a 
Sedigraph $^{2}$ (Fig. 1) indicates that 95 percent of the material was finer than $50 \mu \mathrm{m}$.

3.2 Orthorhombic $\mathrm{C}_{3} \mathrm{~A}$

Orthorhombic $\mathrm{C}_{3} \mathrm{~A}$ was prepared using $31.0 \mathrm{~g} \mathrm{Na}_{2} \mathrm{CO}_{3}, 233.0 \mathrm{~g}$ $\mathrm{CaCO}_{3}$, and $136.1 \mathrm{~g} \mathrm{Al}(\mathrm{OH})_{3}$. These were processed as described above for cubic $C_{3} A$, but were heated at the following schedule: $1.5 \mathrm{hrs}$ at $1400^{\circ} \mathrm{C}$ then $1.0 \mathrm{hr}$ at $1450^{\circ} \mathrm{C}$.

3. 3 MgO

The Mgo was prepared using MgCO3. This was pelletized and heated for $2 \mathrm{hrs}$ at $950^{\circ} \mathrm{C}$, then $0.5 \mathrm{hrs}$ at $1500^{\circ} \mathrm{C}$. It was ground in a pebble mill to a Blaine fineness of $4620 \mathrm{~cm}^{2} / \mathrm{g}$. The particle size distribution is shown in Fig. 2 .

$3.4 \quad \mathrm{C}_{4} \mathrm{AF}$

A sample of $\mathrm{C}_{4} \mathrm{AF}$ that had been prepared previously at CTL was ground in a pebble mill until it passed a $75 \mu \mathrm{m}$ (No. 200) sieve. Details on the preparation of this phase are not available.

\section{CALIBRATION MIXTURES}

Three calibration mixtures in known proportions and two mixtures in unknown proportions were prepared from the calibration phases. The proportions are listed in Table 1 for the calibrating mixtures, and in Table 2 for the unknown mixtures.

The mixing process had a target fineness level of approximately 95 percent finer than $10 \mu \mathrm{m}$. Mixtures were ground using a tungsten carbide swing mill with tungsten carbide ring and puck. Ethylene glycol (reagent grade) was added as a grinding aid, using $50 \mu \mathrm{L}$ per batch. Mixtures were ground $1 \mathrm{~min}$ at $800 \mathrm{rpm}$. The mixtures were brushed into glass vials and sealed. The particle size distribution of a calibration mixture is shown in Fig. 3. According to this distribution, the mixture is somewhat coarser than the target (70 percent, rather than 90 percent, finer than $10 \mu \mathrm{m}$ ).

\footnotetext{
${ }^{2}$ Certain trade names and company products are identified to specify adequately the experimental procedure. In no case does such identification imply recommendation or endorsement by the National Institute of Standards and Technology, nor does it imply that the products are necessarily the best available for the purpose.
} 


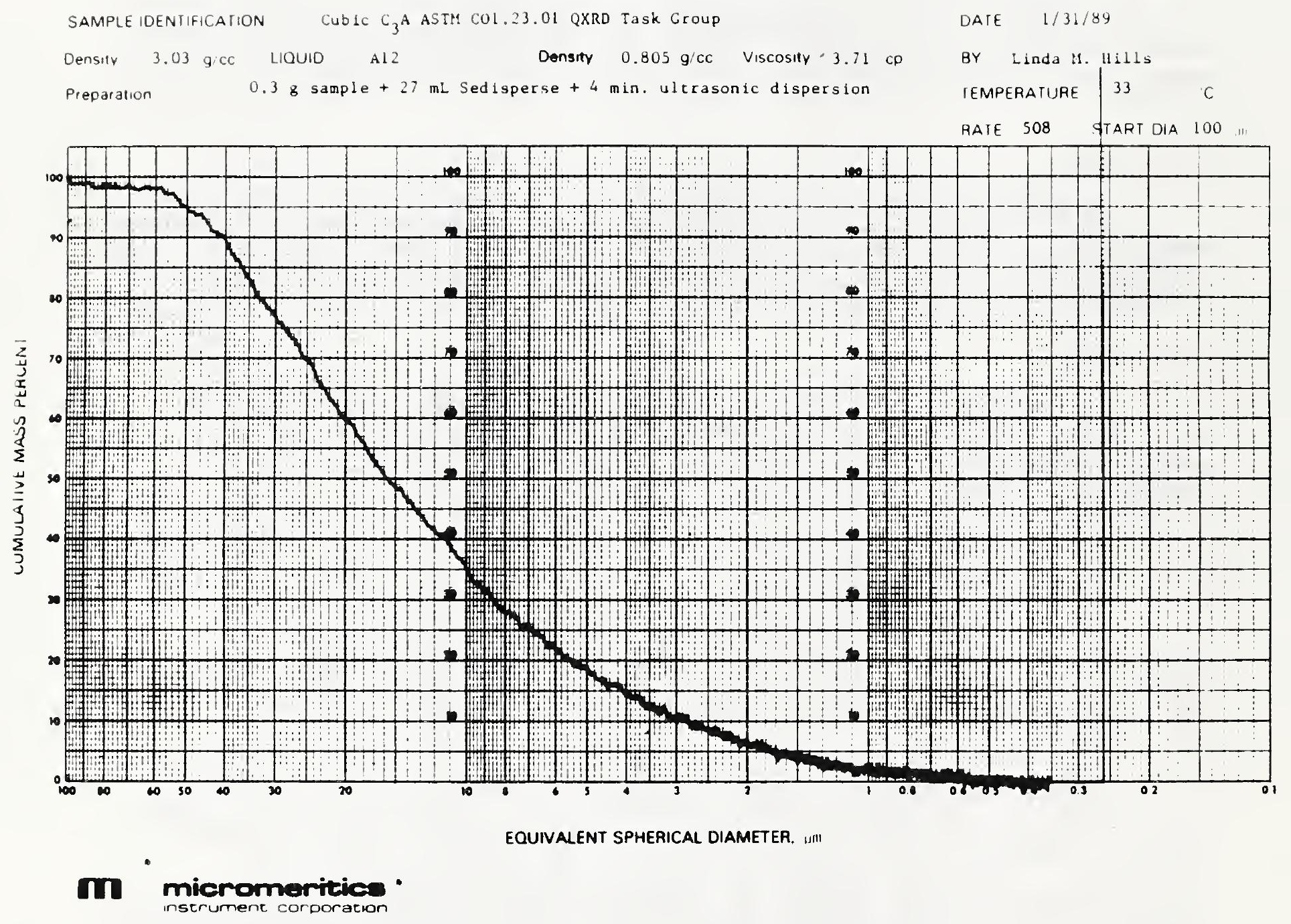

Figure 1. Particle size distribution curve for cubic $C_{3} A$ calibration phase. 
PARTICLE SIZE DISTRIBUTION

SAMPLE IDENTIFICATION ItgO AST:I COI.23.01 QXRD Task Group

Densily $3.58 \mathrm{~g} / \mathrm{Cc} \quad$ LIQUID Al2 Density 0.805 g/cc Viscosity $3.71 \mathrm{c \rho}$

Preparation $0.3 \mathrm{~g}$ sample $+27 \mathrm{~mL}$ Sedisperse $+4 \mathrm{~min}$. ultrasonic dispersion

DAIE $\quad 1 / 31 / 89$

By Linda M. H111s

IEMPERATURE

RAIE 637 START DIA 100

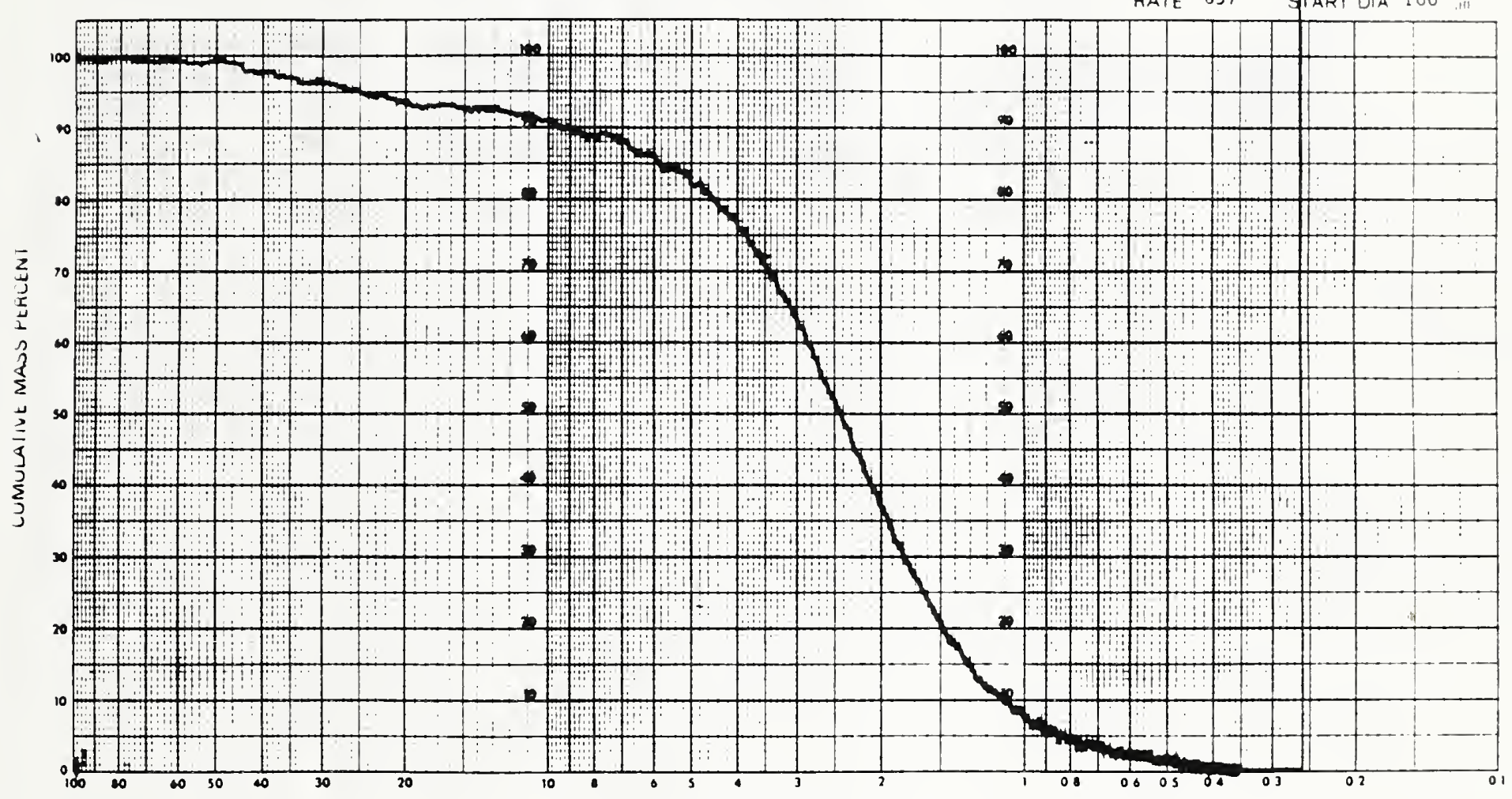

EQUIVALENT SPHFRICAL DIAMETER phase. 
Table 1

Calibration Mixtures

percent of mixture percent of clinker
A
B
C
A
B
C

$\mathrm{C}_{3} \mathrm{~A}$

Cubic

orthorhombic

11

51

29

11.05

1. 87

8.67

4.93

0

11

60

5.95

1.87

1.19

$\mathrm{C}_{4} \mathrm{AF}$

27

0.0

4.59

10.20

MgO

0

4

0.68 


$$
\begin{aligned}
& \text { Table } 2 \\
& \text { Proportions Used in Unknown Mixtures } \\
& \text { percent of mixture } \\
& \text { (\% of extraction residue) } \\
& \text { Unknown } 1 \text { Unknown } 2
\end{aligned}
$$

orthorhombic $C_{3} A$ cubic $\mathrm{C}_{3} \mathrm{~A}$

$\mathrm{C}_{4} \mathrm{AF}$

$\mathrm{MgO}$
0.0

20.0

58.0

22.0
7.0

63.0

26.0

4.0
0.00

3.00

8.70

3.30
1.05

9.45

3.90

0.60 
PARTICLE SIZE DISIRIBUIIUN

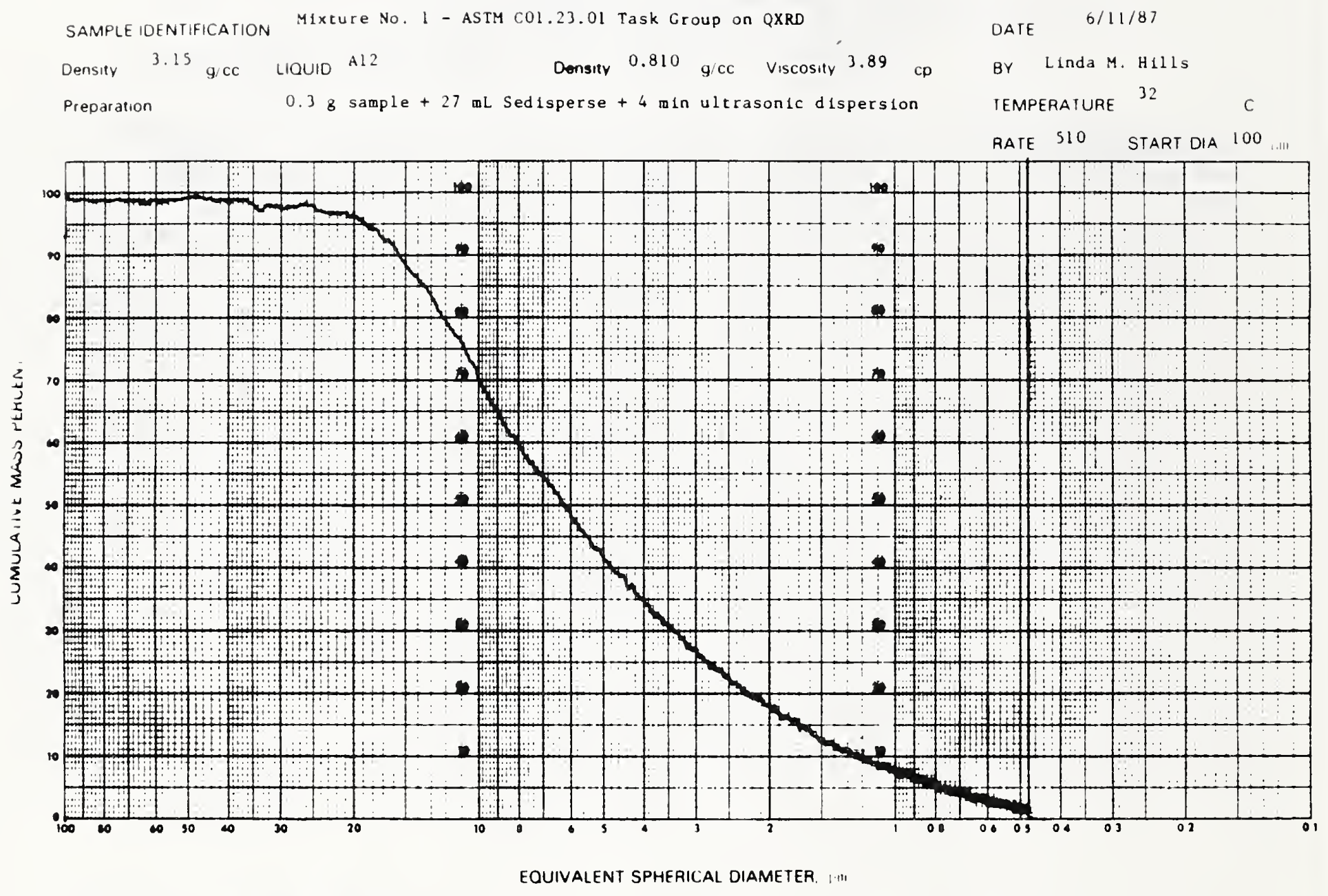

III mioromertio:

Figure 3. Particle size distribution curve for calibration mixture No. 1 . 
It was required that participants use an internal standard. The internal standard was specified to be a pure, stable material, 95 percent of which was finer than $10 \mu \mathrm{m}$. The choice of material was left up to each participant; recommended materials were NIST SRM $640 a$ (silicon) or one of the materials included in SRM 674 (especially the $\mathrm{TiO}_{2}$ ). Recommended proportions were $0.12000 \mathrm{~g}$ internal standard per $1.00000 \mathrm{~g}$ calibration or unknown mixture (corresponding to $0.0200 \mathrm{~g}$ internal standard per $1.0000 \mathrm{~g}$ clinker).

\section{ANALYTICAL PROCEDURES}

The calibration and unknown mixtures were mixed with the internal standard material by the participants. Participants were required to weigh out each mixture and to blend with the internal standard. Components were weighed to the nearest $0.0001 \mathrm{~g}$ using an analytical balance. They were blended to provide homogeneous specimens; the recommended method was to blend each calibration mixture for approximately 10 minutes using a vibratory-type mill, with approximately $5 \mathrm{ml}$ of a non-aqueous solvent such as Freon for each gram of powder, and with appropriate grinding media. Suitable mills include the spex Mixer Mill.

Participants were instructed to use their normal procedures for specimen preparation and for collecting the diffraction patterns. The operating parameters for collecting diffraction patterns are difficult to specify, as they depend on the particular instrument. The parameters recommended for accurate and reproducible intensity measurements were slow scanning speeds and moderately large receiving-slit widths.

Participants were also instructed to scan and measure the intensities of as many peaks as possible for each phase, including but not limited to those peaks listed in Table 3 . Peak intensities were to be measured using the integrated intensity of the peak above the background.

Participants then developed calibration curves relating the measured intensity of the XRD peaks for each phase, relative to the intensity of the internal standard peak, to the known proportion of the phase. This could be done graphically, or using a computer to determine the best-fitting (i.e. least squares) line.

As a preliminary assessment of the calibration, each participant used the calibration results to determine the proportion of each phase in two mixtures prepared using the same calibrating phases. The participants did not know these proportions (Table 2). The two unknown mixtures were prepared and analyzed in triplicate (i.e., three replicate preparations of 
Peaks Recommended for QXRD Analysis

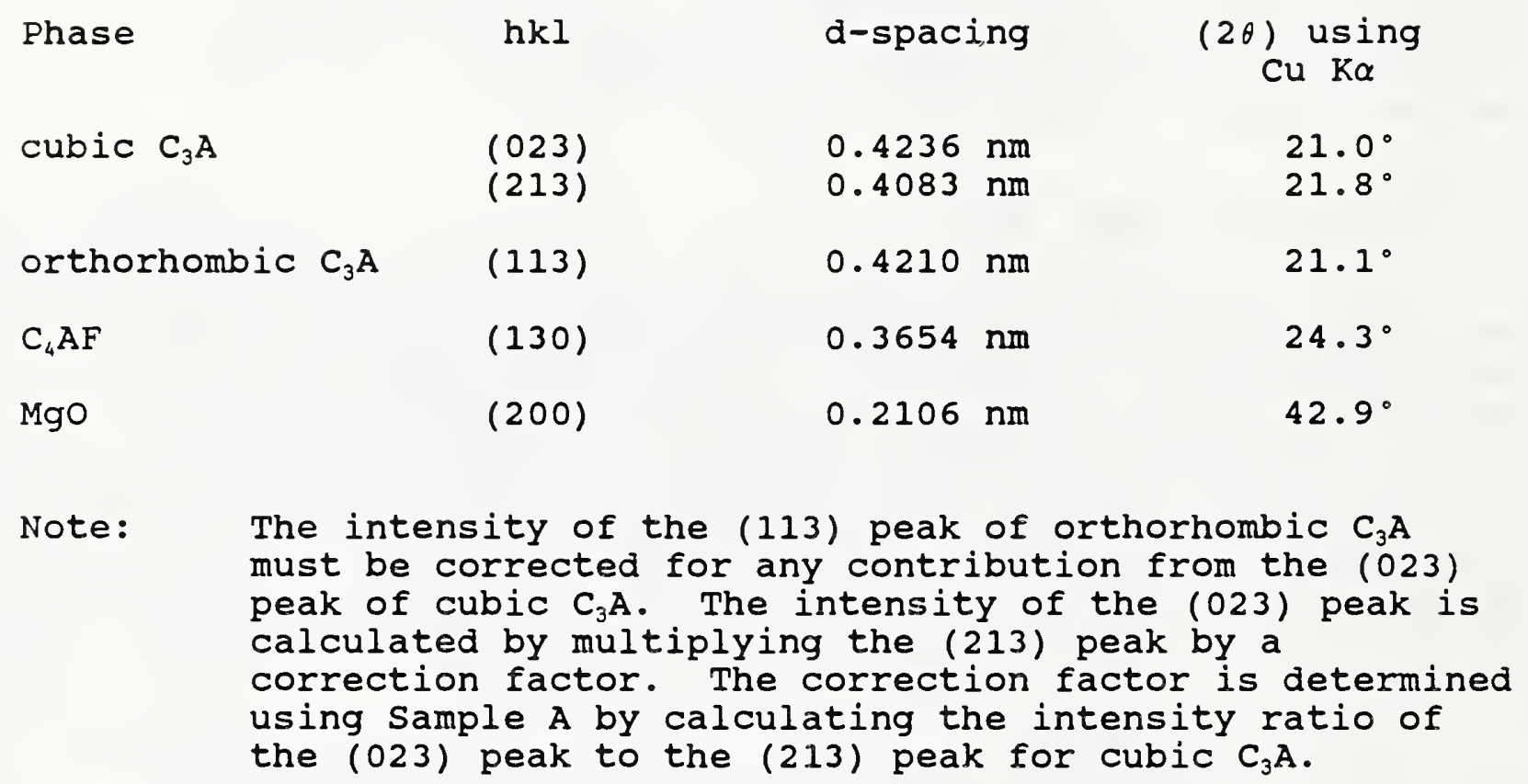


each specimen). In order to improve the statistical reliability of the results, the replicate specimens of the two unknown mixtures were interleaved (i.e., a specimen of one unknown was prepared and analyzed, than a specimen of the other unknown prepared and analyzed, etc.). The same procedures were followed that had been used in the calibration mixtures for collecting diffraction patterns and measuring integrated peak intensities. The amount of each phase in each replicate of the two unknown samples was then calculated using the calibrations obtained in the first part of this analysis.

\section{RESULTS ON UNKNOWN MIXTURES}

The individual results reported by each laboratory are listed in Appendix 2 and summarized graphically in Figs. 4 through 8 .

The results were analyzed statistically to estimate precision and bias. The objective of the statistical analysis was to provide precision and bias levels to include in the subsequent proposed standard test method. The precision analysis followed the procedure of ASTM E 691. The statistical analysis is described in detail in Appendix 3 of this report. There were 8 materials (each phase in each unknown were treated as a separate material), and 7 laboratories ${ }^{3}$.

The critical values of the consistency statistics ( $h$ and $k$ ) were exceeded only by one laboratory (Laboratory 3). Examination of the XRD patterns provided by this laboratory showed a considerably higher noise level and lower intensity ratio of peak/background compared to patterns of other participating laboratories. Therefore, it was decided that the results reported by Laboratory 3 were not as consistent as expected from this analysis, and the final statistical analysis did not include results from Laboratory 3 .

The statistical analysis from Appendix 3 is summarized in Table 4. Note that results in Appendix 3 are expressed as a percent of the mixture, whereas results in Table 4 have been converted to a percent of clinker ${ }^{4}$.

The average measured values (Table 4) agree well with the known values (Table 2). In nearly every instance these values differ by less than the reproducibility standard deviation ( $s_{R}$ in

\footnotetext{
${ }^{3}$ Laboratories 4 and 7 did not report replicate results and therefore could not be used in this statistical analysis.

${ }^{4}$ For this calculation, each mixture was considered to represent 17 percent of a hypothetical clinker.
} 


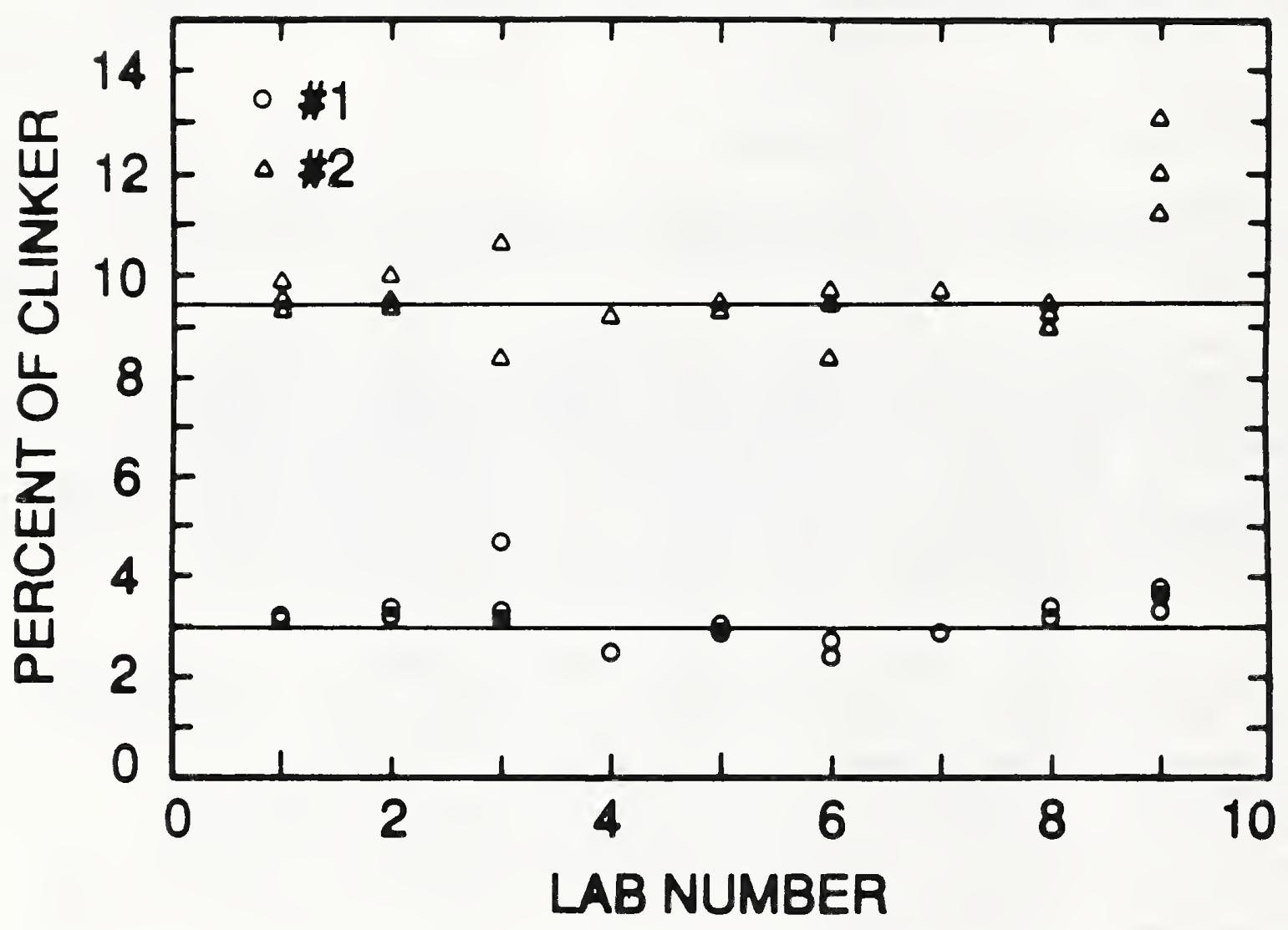

Figure 4. Results from QXRD analysis of cubic $C_{3} A$ showing actual value for Unknown \#I (lower Iine) and Unknown \#2 (upper line). 


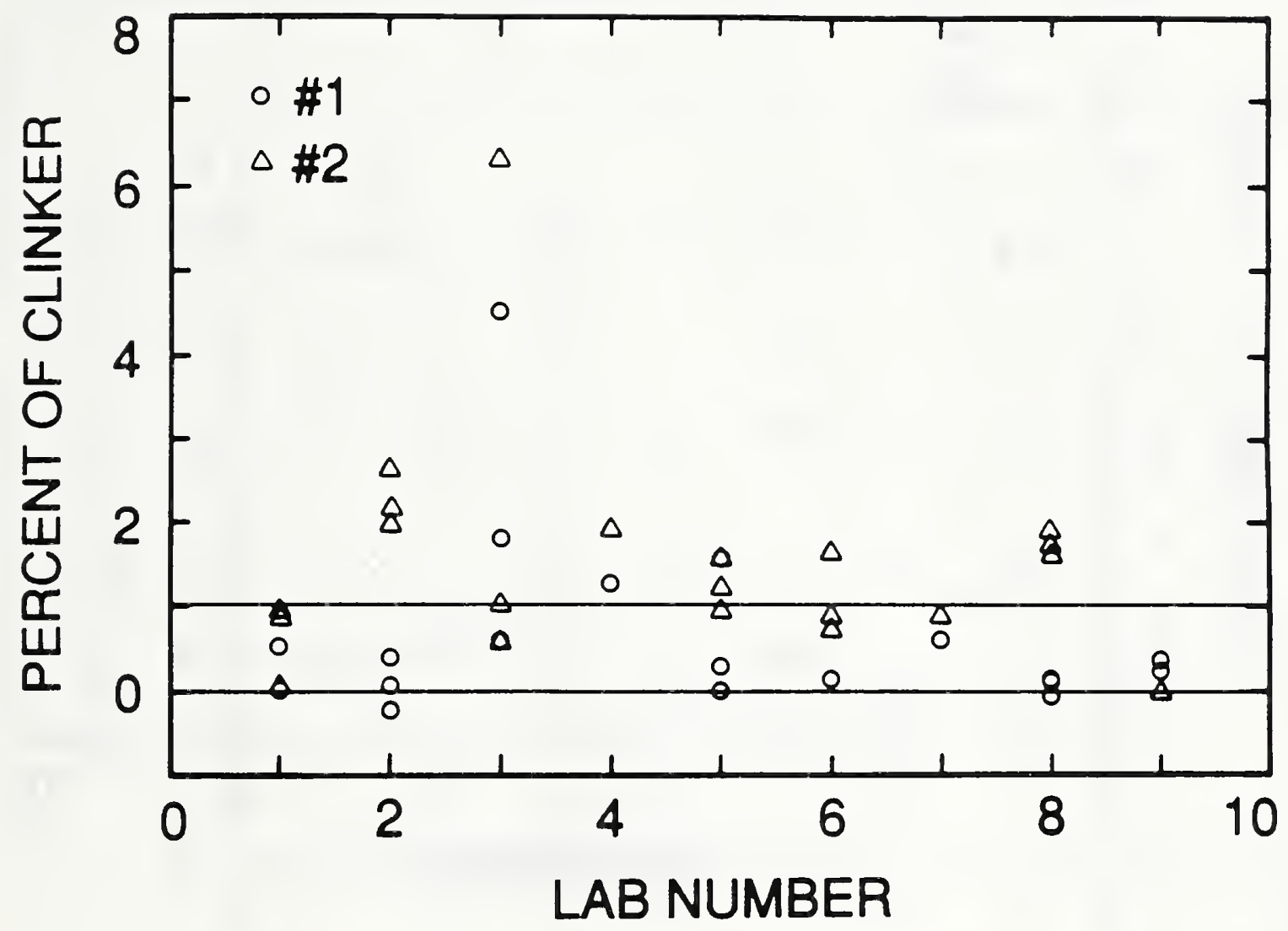

Figure 5. Results from QXRD analysis of orthorhombic $C_{3} A$ showing actual value for Unknown \#I (lower line) and Unknown \#2 (upper line). 


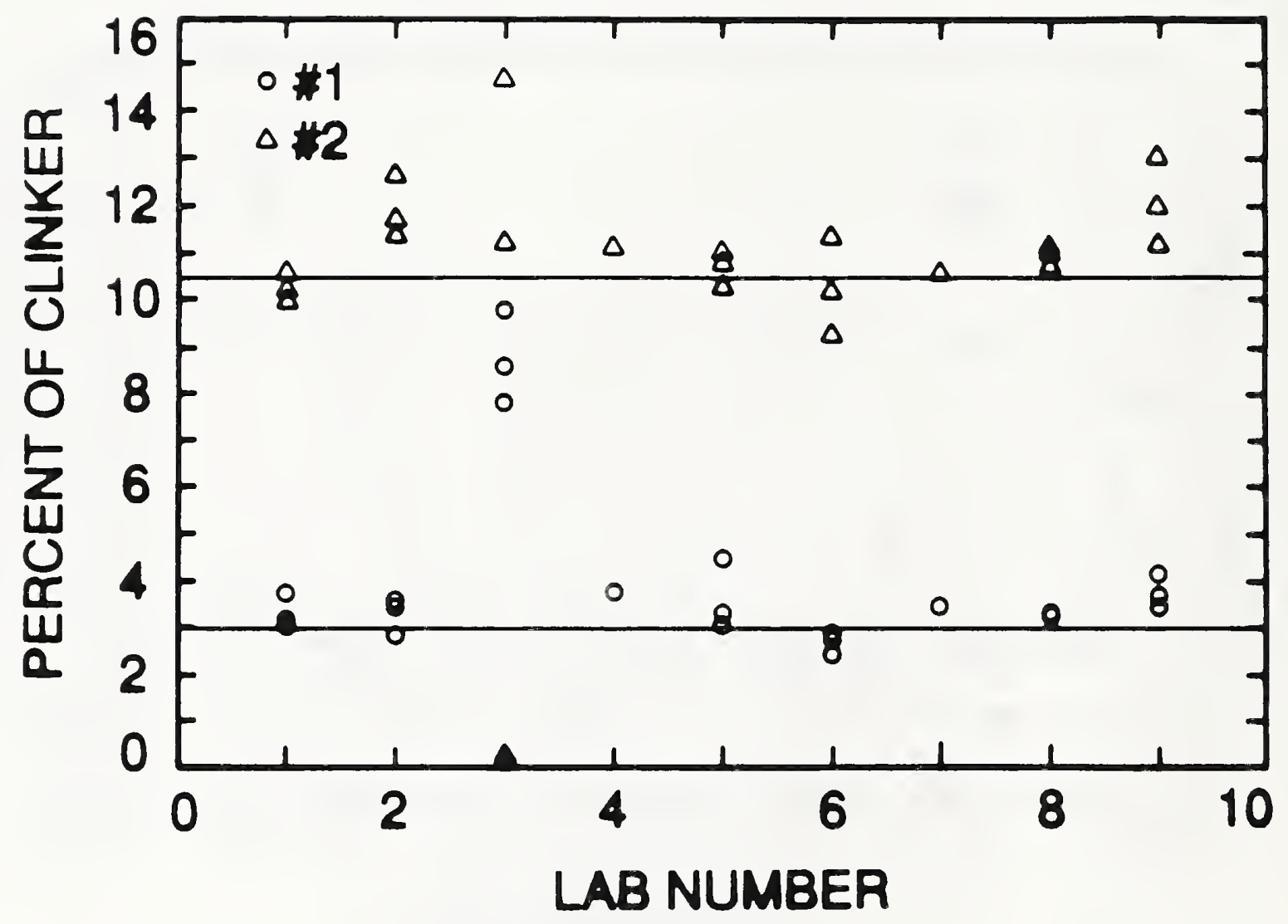

Figure 6. Results from QXRD analysis of $C_{3} A$ (cubic plus orthorhombic) showing actual value for Unknown \#1 (lower line) and Unknown \#2 (upper line). 


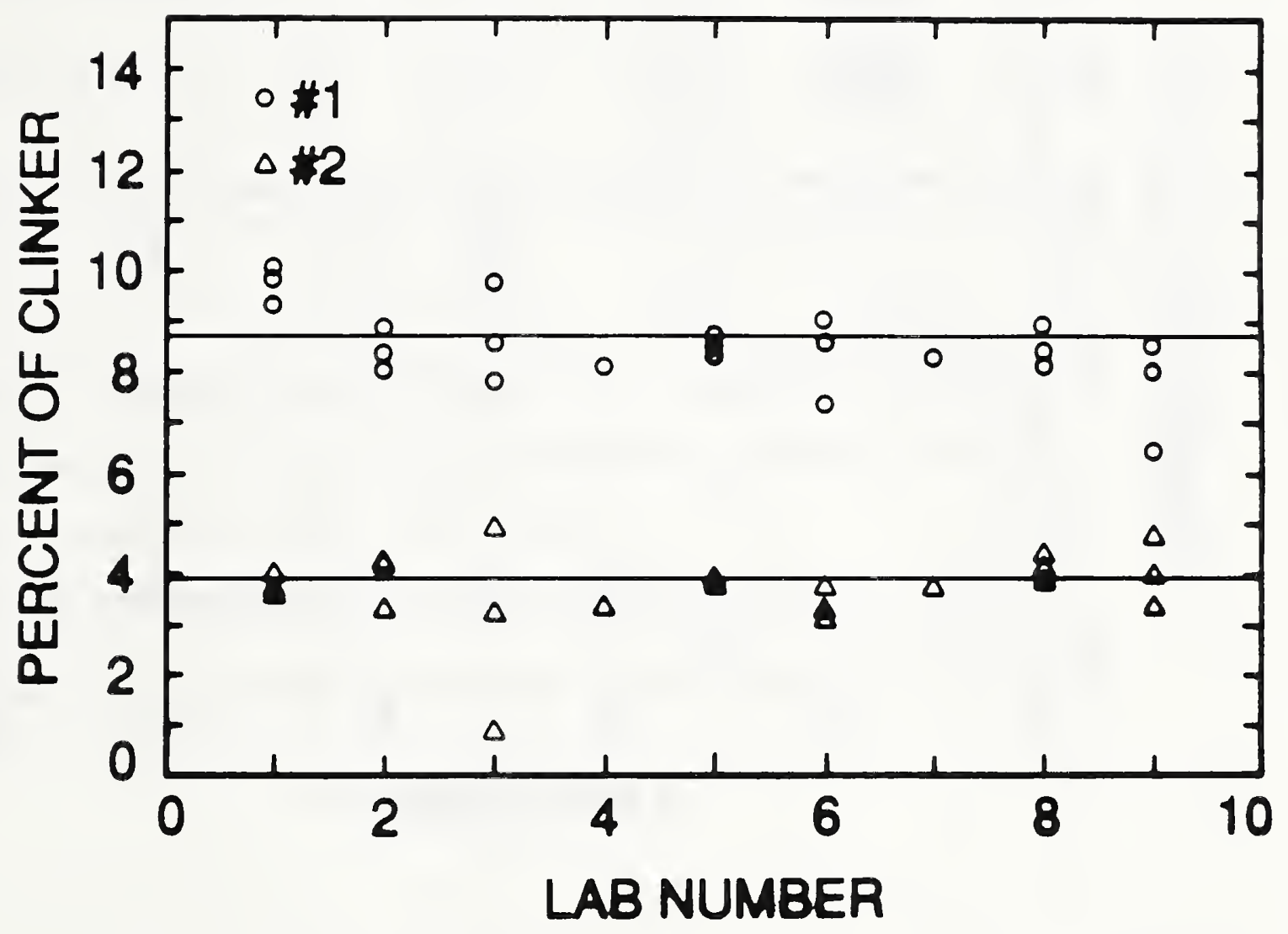

Figure 7. Results from QXRD analysis of $C_{4} A F$ showing actual value for Unknown \#1 (upper line) and Unknown \#2 (lower line). 


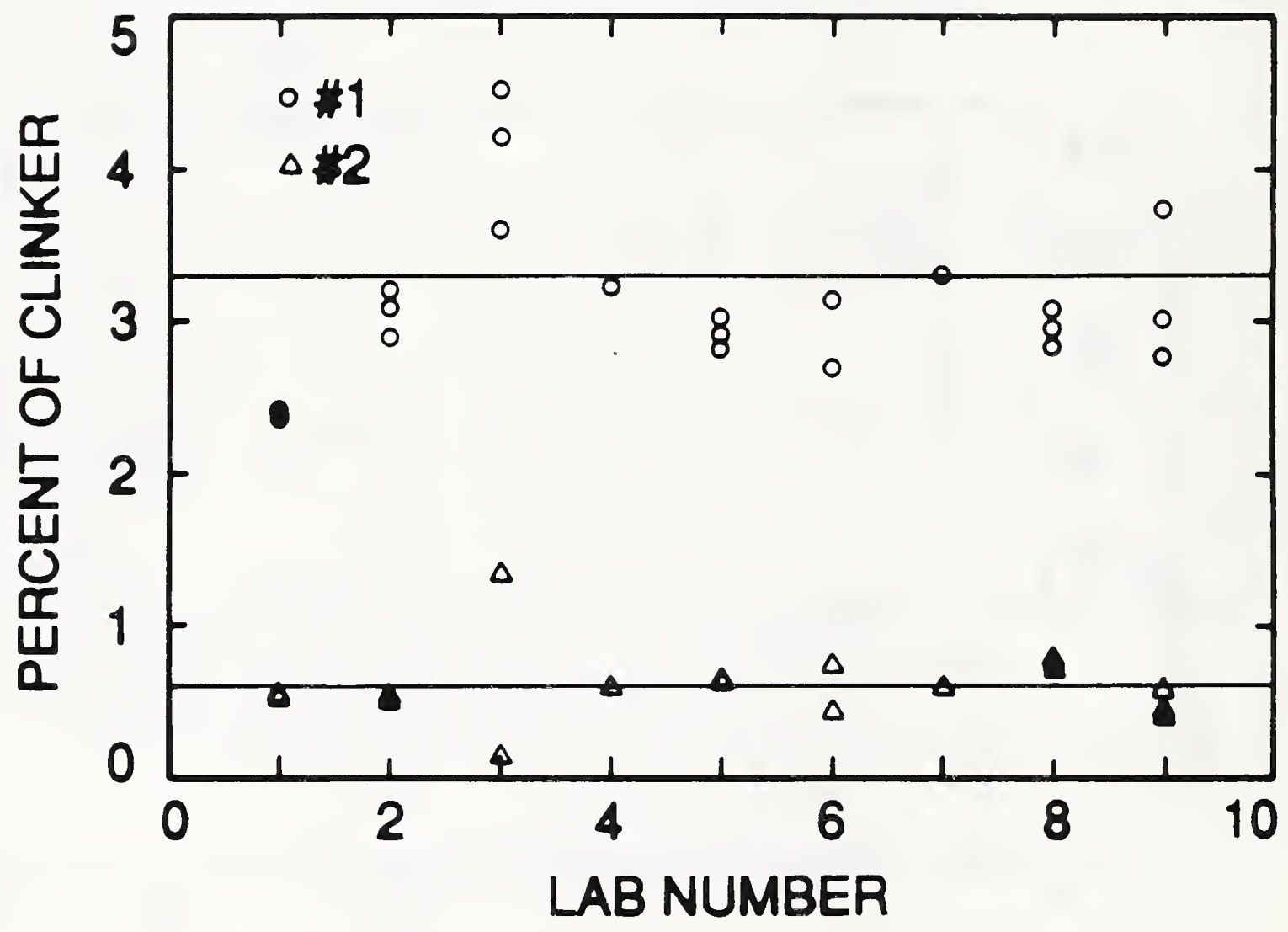

Figure 8. Results from QXRD analysis of Mgo showing actual value for Unknown \#1 (upper Iine) and Unknown \#2 (lower line). 
Table 4

Summary of Statistical Analysis

(percent of clinker)

standard deviation

Phase

Unknown Average
$95 \%$ Limit

$r^{c}$

1.25

1.10

0.45

0.97

0.51

1.65

0.39

0.18
0.59

1.35

0.72

0.98

0.47

2.03

1.27

2.74

0.45

0.38

0.28

0.14

0.78

0.26

1.08

$\begin{array}{ll}1 & 3.31 \\ & 0.67\end{array}$

arepeatability (within laboratory) standard deviation

${ }^{b}$ reproducibility (between laboratory) standard deviation

${ }^{c}$ repeatability limit ( 2.8 times $s_{r}$ )

${ }^{d}$ reproducibility limit ( 2.8 times $\left.s_{R}\right)$ 
Table 4). Thus there appears to be no bias in these test results.

Based on the estimated levels of repeatability standard deviation $\left(s_{r}\right.$ in Table 4 ), the limit for 95 percent repeatability ( $r$ in Table 4 ) averaged 1.1 percent (relative to the total clinker) and ranged from 0.3 percent to 2.0 percent for the phases in this interlaboratory test. Likewise, the limit for 95 percent reproducibility ( $R$ in Table 4 ) averaged 1.8 percent (relative to the total clinker) and ranged from 0.4 percent to 3.8 percent.

These precision indices will form the basis for repeatability and reproducibility levels to be specified in the proposed standard test method being developed by Task Group C01.23.01 for analysis of cubic $C_{3} A$, orthorhombic $C_{3} A, C_{4} A F$, and Mgo. Single values for repeatability and reproducibility indices are reported here. However, the standard deviation levels and corresponding precision indices are not necessarily equal for all phases. To estimate these levels for each individual phase, additional unknown mixtures are required in the cooperative calibration and analysis. The interlaboratory tests planned by the task group may provide sufficient data to estimate individual levels.

\section{CONCLUSIONS}

Calibrations have been carried out for quantitative X-ray diffraction analysis of cubic $C_{3} A$, orthorhombic $C_{3} A, C_{4} A F$, and Mgo. The calibrations were then used to analyze for these phases in two unknown mixtures. In nearly every instance, the measured value in the unknown mixture differed from the known value by less than the reproducibility standard deviation. Thus there appears to be no bias in these results.

Based on these results, the following repeatability and reproducibility levels may be specified for analyses of cubic $C_{3} A$, orthorhombic $C_{3} A, C_{4} A F$, and $M g O$ in mixtures of phases used for the calibration:

1. replicate analyses in the same laboratory should differ by no more than 1.1 percent (relative to the total clinker), and

2. each result should differ from the known value by no more than 1.8 percent (relative to the total clinker). 


\section{ACKNOWLEDGEMENTS}

This report reflects the effort of those members of ASTM Task Group C01.23.01 who participated in the cooperative calibration. Work by CTL was supported by the Portland cement Association under Project HA4003. We wish to acknowledge assistance by Fulvio Tang at the construction Technologies Laboratory in preparing and analyzing the calibration phases and mixtures, and by John Mandel at NIST in the statistical analysis. 
Laboratories Participating in Cooperative Calibration

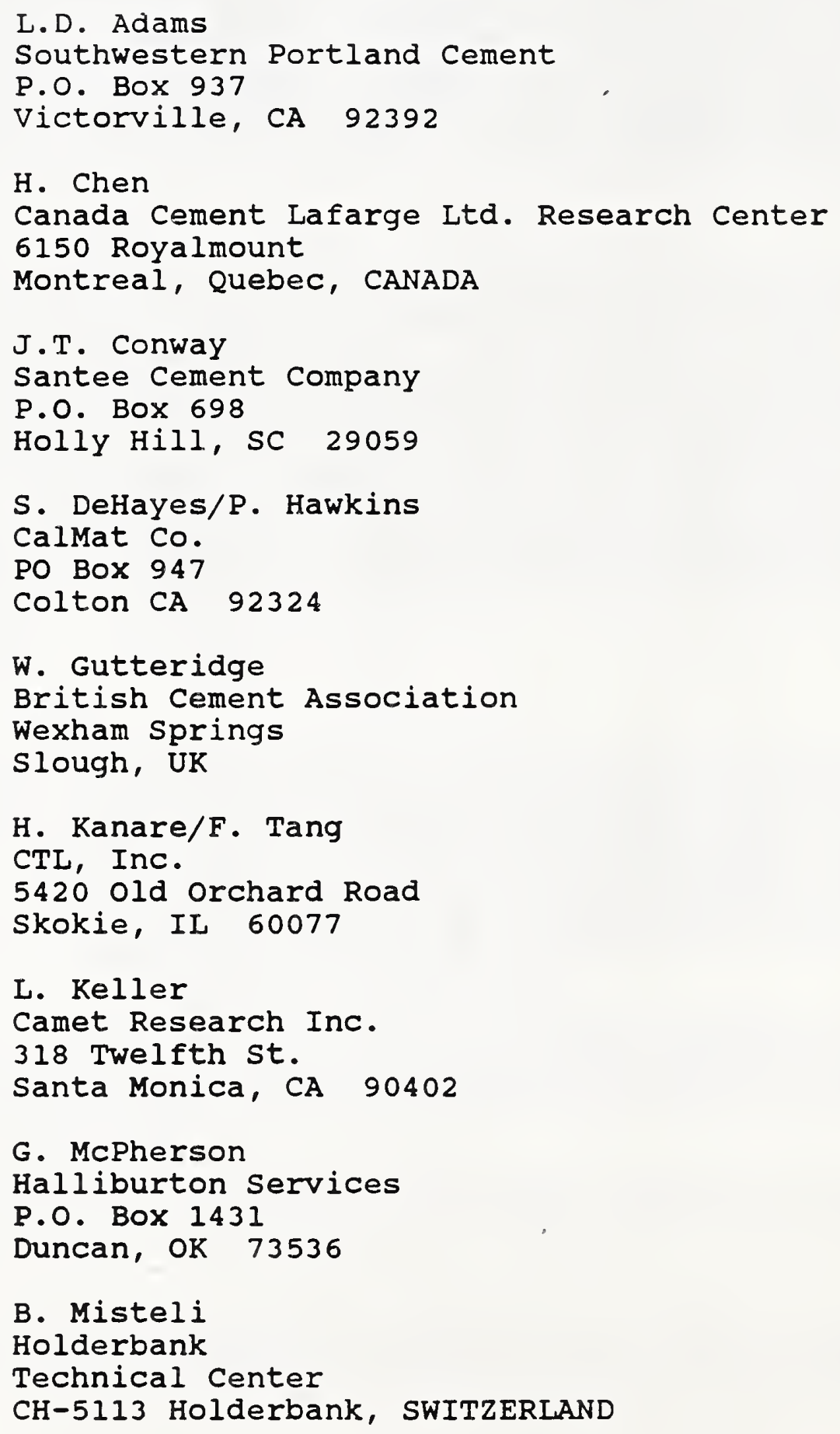




\section{APPENDIX 2 \\ Summary of Results}

2. I Laboratory No. 1

2.1.1 Specified Method

Internal standard: $\mathrm{TiO}_{2}$, NIST SRM 674

Mixing method: Bleuler Mill, $1.7600 \mathrm{~g}$ mixture and $0.2400 \mathrm{~g} \mathrm{TiO}_{2}$

Instrument: computerized diffractometer

Peaks, $(2 \theta)$ for $\mathrm{Cu} \mathrm{K} \alpha$ :

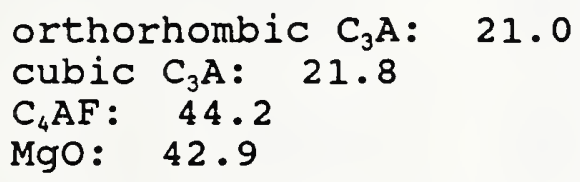

Peak intensities: measured by computer

\section{Results}

(percent of mixture)

Unknown 1 Unknown 2

\begin{tabular}{|c|c|c|}
\hline cubic $C_{3} A$ & $\begin{array}{l}21.1 \\
20.2 \\
21.4\end{array}$ & $\begin{array}{l}62.4 \\
66.2 \\
64.1\end{array}$ \\
\hline orthorhombic $\mathrm{C}_{3} \mathrm{~A}$ & $\begin{array}{l}0.0 \\
0.0 \\
3.4\end{array}$ & $\begin{array}{l}6.1 \\
0.5 \\
6.6\end{array}$ \\
\hline $\mathrm{C}_{4} \mathrm{AF}$ & $\begin{array}{l}65.6 \\
62.1 \\
67.2\end{array}$ & $\begin{array}{l}24.4 \\
24.8 \\
26.9\end{array}$ \\
\hline Mgo & $\begin{array}{l}15.7 \\
16.1 \\
15.9\end{array}$ & $\begin{array}{l}3.5 \\
3.5 \\
3.8\end{array}$ \\
\hline
\end{tabular}


2.1.2 Additional Methods

Peak intensities measured manually

External standard (quartz, 36.5)

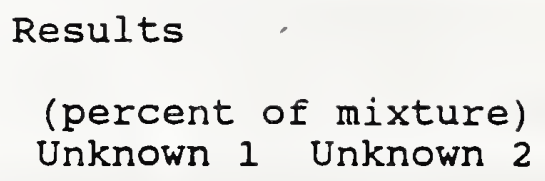

cubic $\mathrm{C}_{3} \mathrm{~A}$

orthorhombic $\mathrm{C}_{3} \mathrm{~A}$

$\mathrm{C}_{4} \mathrm{AF}\left(24.3^{\circ}\right.$ peak)

$\mathrm{C}_{4} \mathrm{AF}\left(12.1^{\circ}\right.$ peak)

MgO
20.3

20.5

3.8

2.6

65.3

65.6

67.2

66.2

15.3

15.4

3.9

3.6 
2.2 Laboratory No. 2

2.2.1 Specified Method

Internal standard: $\mathrm{TiO}_{2}$ (rutile)

Mixing method: Spex Mixer Mill, 5 min

Instrument: computerized diffractometer

Peaks, $(2 \theta)$ for $\mathrm{Cu} \mathrm{K} \alpha$ :

orthorhombic $\mathrm{C}_{3} \mathrm{~A}: 20.56-21.33$

cubic $C_{3} A: 21.33-22.05$

$\mathrm{C}_{4} \mathrm{AF}: 23.60-24.89$

MgO: $42.38-43.58$

Results

(percent of mixture)

Unknown 1 Unknown 2

cubic $\mathrm{C}_{3} \mathrm{~A}$

20.23

21.15

66.91

22.44

63.60

$-1.48$

62.82

orthorhombic $\mathrm{C}_{3} \mathrm{~A}$

2.61

17.71

0.36

14.72

13.32

$\mathrm{C}_{4} \mathrm{AF}$

53.55

59.13

55.69

28.29

28.69

22.33

Mgo

19.32

20.61

3.8

3.46

21.34

3.52 
2.3 Laboratory No. 3

\subsubsection{Specified Method}

Internal standard: $\mathrm{Si}$

Mixing method: ring-and-puck mill, $4.5000 \mathrm{~g}$ mixture, $0.5000 \mathrm{~g}$ Si, freon, $1 \mathrm{~min}$

Instrument: computerized diffractometer (Rigaku

Peaks, $(2 \theta)$ for $\mathrm{Cli} \mathrm{K} \alpha$ :

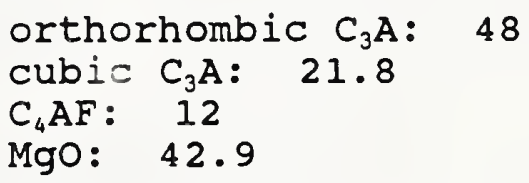

Peak intensities: measured by computer

Results

(percent of mixture)

Unknown 1 Unknown 2

$\begin{array}{lcr}\text { cubic } \mathrm{C}_{3} \mathrm{~A} & 21 . & 56 . \\ & 22 . & 71 . \\ & 31 . & -5 . \\ \text { orthorhombic } \mathrm{C}_{3} \mathrm{~A} & 30 . & 42 . \\ & 4 . & 4 . \\ & 12 . & 7 . \\ \mathrm{C}_{4} \mathrm{AF} & & \\ & 57 . & 33 . \\ & 65 . & 22 . \\ \text { MgO } & 52 . & 6 . \\ & & \\ & 28 . & 9 . \\ & 24 . & 9 . \\ & 30 . & 1 .\end{array}$

Comments: noisy pattern with low peak/background ratio (for Unknown \#2, the peak/background ratio for the $C_{4} A F$ peak at $34^{\circ}$ is 1.5 ; the ratio obtained by Laboratory 2 for the same peak is 63); no angle scale was provided, so peak positions and alignment cannot be assessed. 
2. 4 Laboratory No. 4

2.4.1 Specified Method

Internal standard: $\mathrm{TiO}_{2}$ (rutile)

Instrument: computerized diffractometer (Siemens)

Peaks, $(2 \theta)$ for $\mathrm{Cu} \mathrm{K} \alpha$ :

all peaks for each phase in range $25^{\circ}$ to $38^{\circ}$

Peak intensities: measured by computer

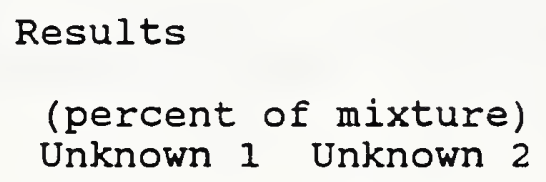

cubic $\mathrm{C}_{3} \mathrm{~A}$

16.5

61.5

orthorhombic $C_{3} A$

$8.5 \quad 13.0$

$\mathrm{C}_{4} \mathrm{AF}$

$54.0 \quad 22.5$

MgO

21.5

4.0 
2.5 Laboratory No. 5

2.5 .1 Specified Method

Internal standard: Si, NIST SRM $640 \mathrm{~b}$

Mixing method: Bleuler Mill, $30 \mathrm{sec}$

Instrument: manual diffractometer (Philips)

Peaks, $(2 \theta)$ for $\mathrm{Cu} \mathrm{K} \alpha$ :

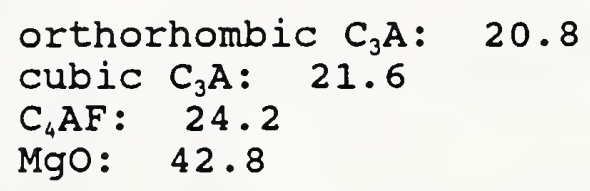

Peak intensities: measured using planimeter

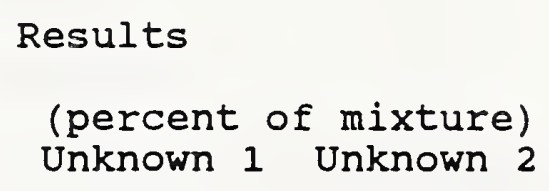

cubic $\mathrm{C}_{3} \mathrm{~A}$

orthorhombic $C_{3} A$

$\mathrm{C}_{4} \mathrm{AF}$

Mgo

$\begin{array}{rr}19.2 & 63.1 \\ 20.0 & 62.3 \\ 20.3 & 63.9 \\ 10.4 & 10.7 \\ 1.9 & 6.5 \\ 0.0 & 8.4 \\ 55.5 & 26.2 \\ 58.1 & 25.6 \\ 56.6 & 26.4 \\ 19.4 & \\ 20.1 & 4.4 \\ 18.8 & 4.3 \\ & 4.3\end{array}$


2. 6 Laboratory No. 6

2.6.1 Specified Method

Internal standard: Si (12 percent), NIST SRM 640b

Mixing method: Spex Mill, $1.0000 \mathrm{~g}$ mixture, $0.1200 \mathrm{~g} \mathrm{Si}$, and cyclohexane

Instrument: computerized diffractometer (Norelco)

Peaks, $(2 \theta)$ for $\mathrm{Cu} \mathrm{K} \alpha$ :

for each phase, all peaks within the region between $27^{\circ}$ and $36^{\circ}$ and the region between $39^{\circ}$ and $49^{\circ}$.

Peak intensities: measured by computer using profile fitting algorithm (Savitzky and Golay)

\section{Results \\ (percent of mixture) \\ Unknown 1 Unknown 2}

cubic $\mathrm{C}_{3} \mathrm{~A}$

$\begin{array}{ll}18 . & 65 . \\ 16 . & 56 . \\ 18 . & 63 .\end{array}$

orthorhombic $\mathrm{C}_{3} \mathrm{~A}$

$0 . \quad 11$.

0.6 . 6.

1. 5 .

$\mathrm{C}_{4} \mathrm{AF}$

60. 21.

49.22.

57 . 25 .

Mgo

$\begin{array}{ll}21 . & 3 . \\ 18 . & 3 . \\ 21 . & 5 .\end{array}$


2.7 Laboratory No. 7

2.7.1 Specified Method

Internal standard: Si (12 percent)

Mixing method: Bleuler Mill, $1.0000 \mathrm{~g}$ mixture, $0.1200 \mathrm{~g} \mathrm{Si,} \mathrm{and}$ $5 \mathrm{ml} \mathrm{1,1,1-trichloroethane} \mathrm{for} 6 \mathrm{~min}$

Instrument: computerized diffractometer (Philips APD 3600)

Peaks, $(2 \theta)$ for $\mathrm{Cu} \mathrm{K} \alpha$ :

orthorhombic $\mathrm{C}_{3} \mathrm{~A}: 21.0$

cubic $\mathrm{C}_{3} \mathrm{~A}: 21.8$

$\mathrm{C}_{4} \mathrm{AF}: \quad 12.1$

$\mathrm{C}_{4} \mathrm{AF}: \quad 44.2$

MgO: 42.9

Peak intensities: measured using profile fitting program QPROF Results: normalized to 100 percent and averaged

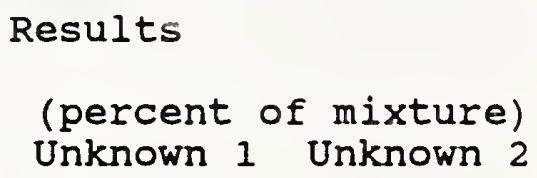

cubic $\mathrm{C}_{3} \mathrm{~A}$

orthorhombic $\mathrm{C}_{3} \mathrm{~A}$

$\mathrm{C}_{4} \mathrm{AF}$

Mgo
19.

4 .

55.

22 .

4 . 
2.8 Laboratory No. 8

2.8.1 Specified Method

Internal standard: $\mathrm{TiO}_{2}$ (12 percent), Rutile

Peaks, $(2 \theta)$ for $\mathrm{Cu} \mathrm{K} \alpha$ :

orthorhombic $\mathrm{C}_{3} \mathrm{~A}: 21.0$

cubic $\mathrm{C}_{3} \mathrm{~A}: 22$

$\mathrm{C}_{4} \mathrm{AF}: 24$

MgO: 43

Peak intensities: measured by computer

\author{
Results \\ (percent of mixture) \\ Unknown 1 Unknown 2
}

cubic $C_{3} \mathrm{~A}$

orthorhombic $\mathrm{C}_{3} \mathrm{~A}$

$\mathrm{C}_{4} \mathrm{AF}$

Mgo
22.4

20.8

20.8

$-0.4$

0.9

0.8

59.4

54.1

55.9

20.5

18.9

19.7
61.8

66.2

64.1

12.7

10.9

11.7

25.8

27.5

29.2

5.3

5.0

4.8 


\subsubsection{Additional Methods}

External standard $\left(\mathrm{CaF}_{2}\right)$

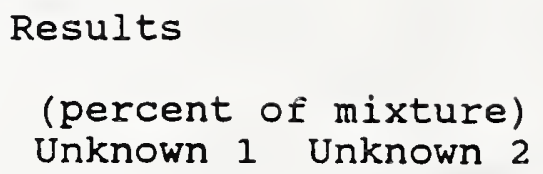

cubic $\mathrm{C}_{3} \mathrm{~A}$

19.9

18.2

19.0

61.0

55.8

orthorhombic $\mathrm{C}_{3} \mathrm{~A}$

1.1

4.2

3.1

10.1

2.4

12.7

$\mathrm{C}_{4} \mathrm{AF} \quad\left(12^{\circ}\right.$ peak $)$

55.0

22.6

55.5

23.7

55.8

21.8

Mgo

19.4

4.5

20.4

5.3

17.9

4.4 
2.9 Laboratory No. 9

2.9.1 Specified Method

Internal standard: $\mathrm{si}$ ( 6 percent)

Instrument: Scintag, computerized diffractometer

Peaks, $(2 \theta)$ for $\mathrm{Cu} K \alpha$ :

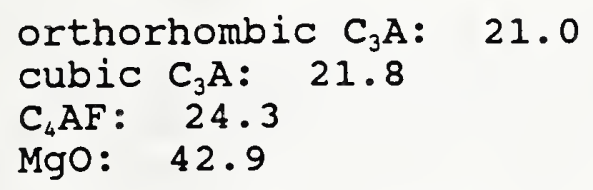

Peak intensities: measured by computer

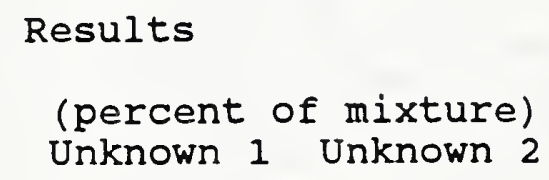

cubic $\mathrm{C}_{3} \mathrm{~A}$

25.0

24.3

21.8

87.2

74.9

orthorhombic $\mathrm{C}_{3} \mathrm{~A}$

2.3

0.0

1.4

0.0

0.0

0.0

$\mathrm{C}_{4} \mathrm{AF}$

56.5

22.6

53.4

31.6

42.6

26.4

Mgo

$\begin{array}{ll}20.1 & 3.1 \\ 24.9 & 3.9 \\ 18.5 & 2.8\end{array}$




\section{Appendix 3}

\section{Statistical Analysis}

The statistical analysis was carried out according to ASTM E691. Of the nine participating laboratories, two were not included (Laboratory 4 and Laboratory 7) because they did not report replicate results.

The statistical analysis treated each phase as a separate material. This is legitimate even though the phases were determined using a single analysis, because each phase is estimated using a separate peak in the $\mathrm{x}$-ray diffraction pattern.

Initial analysis (Tables 3-1 through 3-6) showed that hvalues (Fig. 3-1) and k-values (Fig. 3-2) exceeded critical levels for several analyses by Laboratory 3 . In addition, examination of the XRD patterns provided by this laboratory showed a considerably higher noise level and lower peak/background ratios compared to patterns of other participating laboratories. Therefore, it was decided that the results reported by Laboratory 3 were not representative of the consistency expected from this analysis, and the statistical analysis was repeated without Laboratory 3 .

The analysis excluding Laboratory 3 (Tables 3-7 through 3$8)$ produced the following precision indices: 95 percent repeatability limit $\left(r=2.8 \times s_{r}\right)$ averaged 6.50 and ranged from 1.53 to $11.94 ;$ and 95 percent reproducibility 1 imit $(R=2.8 \mathrm{x}$ $s_{R}$ ) averaged 10.53 and ranged from 2.23 to 22.19 .

A graph of standard deviation levels versus average value (Fig. 3-3) indicates that standard deviation tended to increase slightly as the average value increased, but the correlation coefficients calculated using linear regression analysis (Table 3-9) were only 0.5 to 0.6 . Therefore, it is tentatively concluded that the precision indices be calculated from the average value using the regression constants in Table 3-9. 


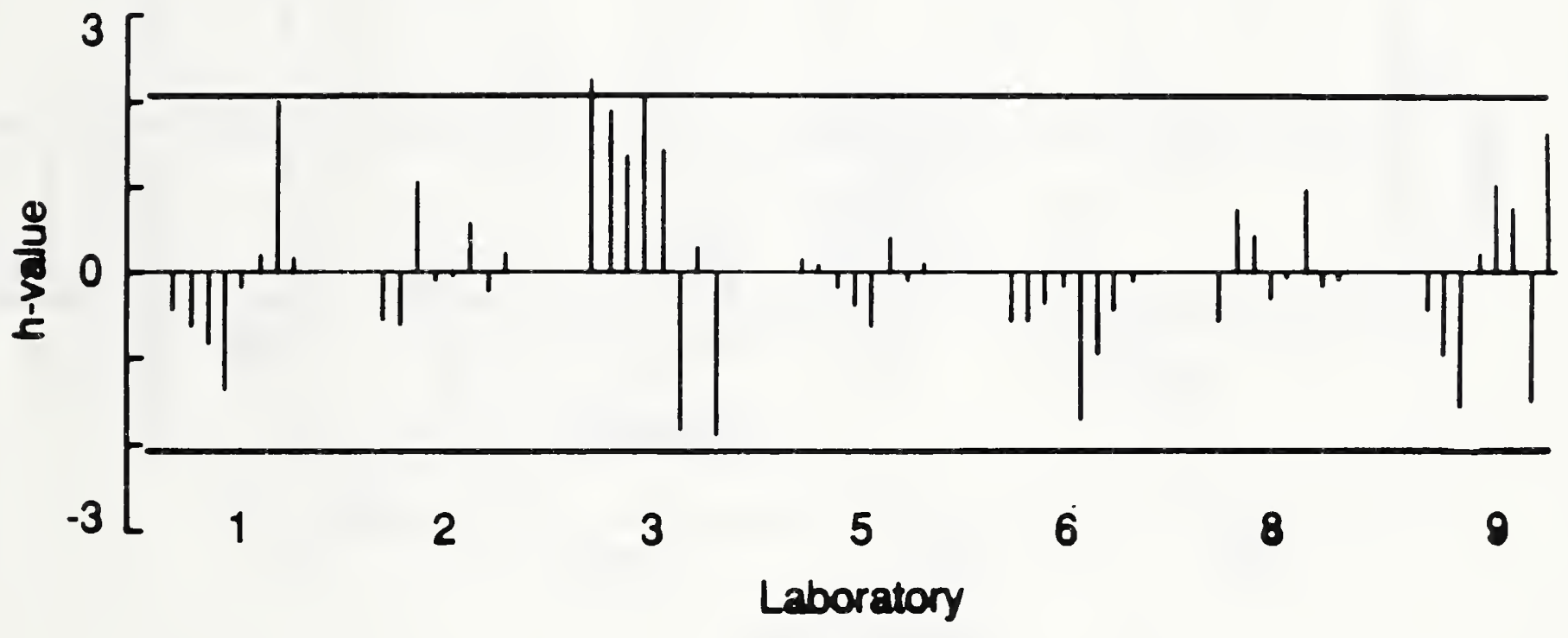

Figure 3-1. Level of h-value for each laboratory (critical values indicated by upper and lower horizontal lines). 


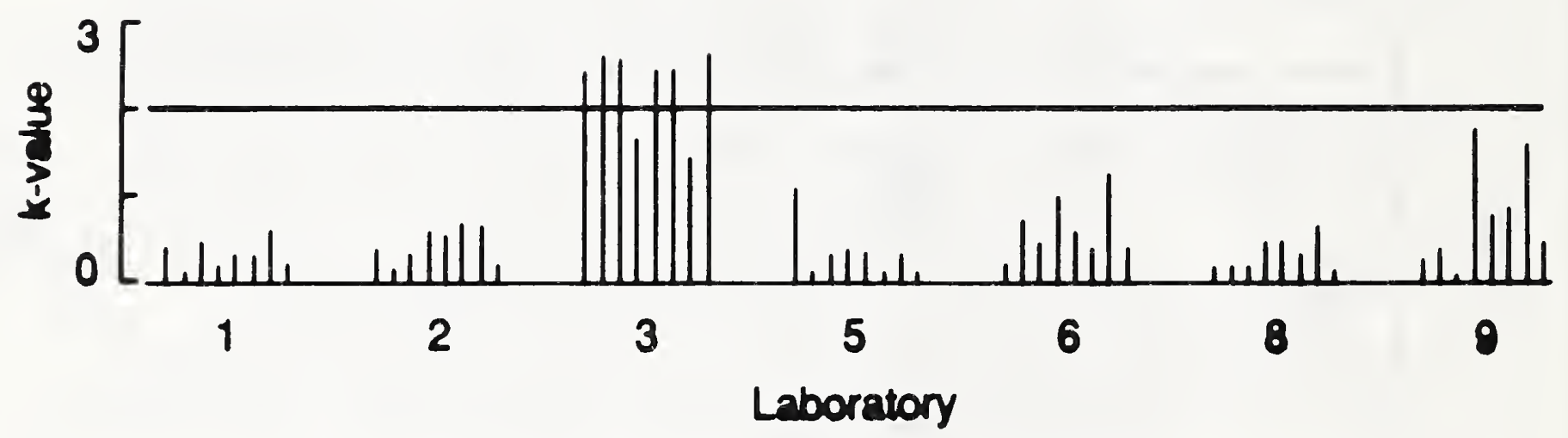

Figure 3-2. Level of k-value for each laboratory (critical value indicated by horizontal line). 


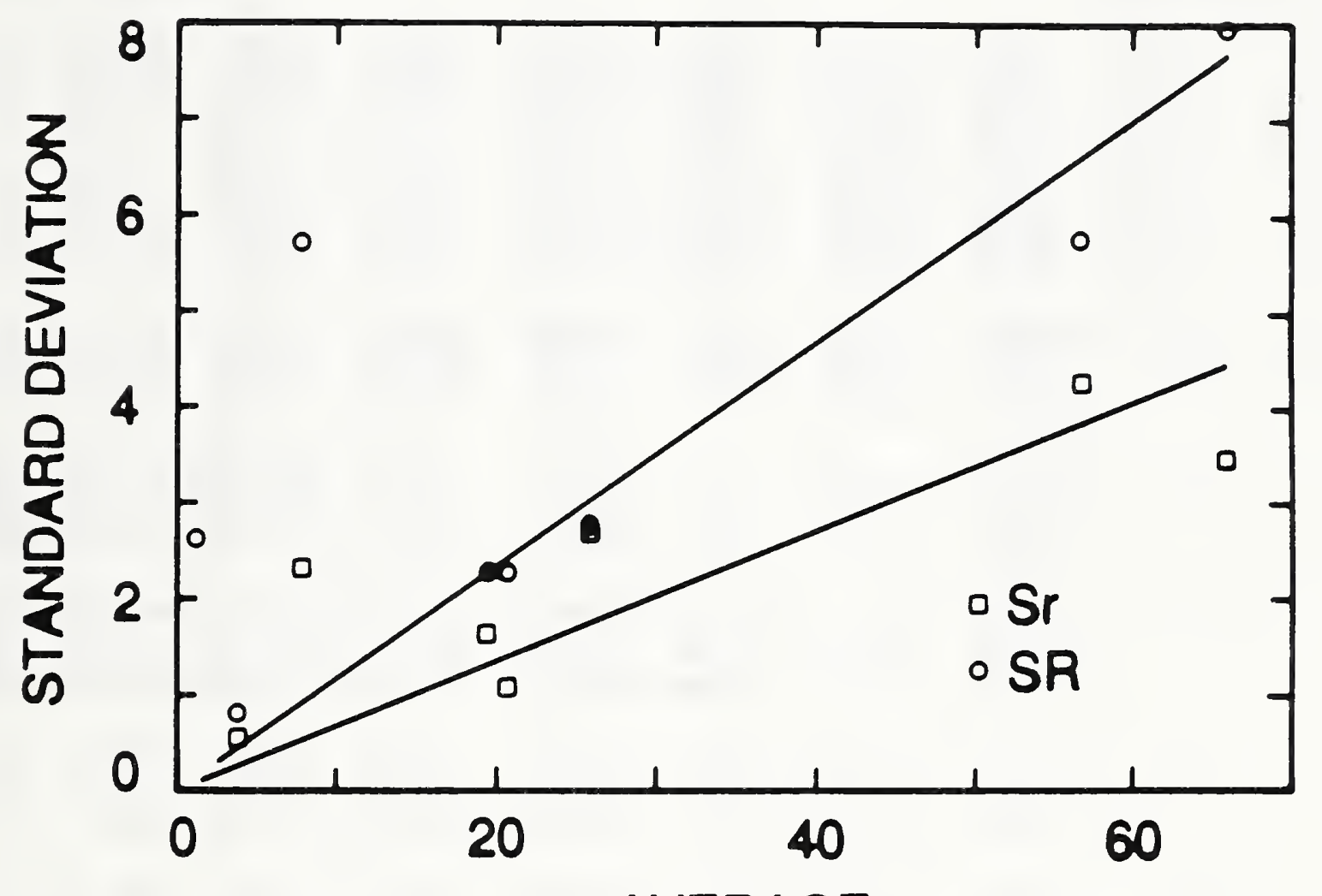

AVERAGE

Figure 3-3. Standard deviation versus average value (relative to the mixture) for each phase in each unknown mixture, showing results of linear regression analysis (Table 3-9). 
Table 3-1

QXRD Results for statistical Analysis (percent of mixture)

$\begin{array}{lcccccccc}\text { or } \mathrm{C}_{3} \mathrm{~A}^{\mathrm{a}} & \mathrm{MgO} & \text { or } \underset{2}{\mathrm{C}_{3} \mathrm{~A}} & \mathrm{MgO} & \mathrm{Cu} \mathrm{C}_{3} \mathrm{~A}^{\mathrm{b}} & \mathrm{C}_{4} \mathrm{AF} & \mathrm{C}_{4} \mathrm{AF} & \mathrm{Cu} & \mathrm{C}_{3} \mathrm{~A}\end{array}$ Laboratory

\begin{tabular}{|c|c|c|c|c|c|c|c|c|}
\hline 1 & $\begin{array}{l}0.00 \\
0.00 \\
3.41\end{array}$ & $\begin{array}{l}3.53 \\
3.53 \\
3.76\end{array}$ & $\begin{array}{l}6.06 \\
0.53 \\
6.59\end{array}$ & $\begin{array}{l}15.71 \\
16.12 \\
15.94\end{array}$ & $\begin{array}{l}21.06 \\
20.24 \\
21.41\end{array}$ & $\begin{array}{l}24.35 \\
24.76 \\
26.94\end{array}$ & $\begin{array}{l}65.59 \\
62.12 \\
67.18\end{array}$ & $\begin{array}{l}62.41 \\
66.24 \\
64.06\end{array}$ \\
\hline & $\begin{array}{r}-1.48 \\
2.61 \\
0.36\end{array}$ & $\begin{array}{l}3.80 \\
3.46 \\
3.52\end{array}$ & $\begin{array}{l}17.71 \\
14.72 \\
13.32\end{array}$ & $\begin{array}{l}19.32 \\
20.61 \\
21.34\end{array}$ & $\begin{array}{l}20.23 \\
21.15 \\
22.44\end{array}$ & $\begin{array}{l}28.29 \\
28.69 \\
22.33\end{array}$ & $\begin{array}{l}53.55 \\
59.13 \\
55.69\end{array}$ & $\begin{array}{l}66.91 \\
63.60 \\
62.82\end{array}$ \\
\hline & $\begin{array}{r}30.00 \\
4.00 \\
12.00\end{array}$ & $\begin{array}{l}9.00 \\
9.00 \\
1.00\end{array}$ & $\begin{array}{r}42.00 \\
4.00 \\
7.00\end{array}$ & $\begin{array}{l}28.00 \\
24.00 \\
30.00\end{array}$ & $\begin{array}{l}21.00 \\
22.00 \\
31.00\end{array}$ & $\begin{array}{r}33.00 \\
22.00 \\
6.00\end{array}$ & $\begin{array}{l}57.00 \\
65.00 \\
52.00\end{array}$ & $\begin{array}{r}56.00 \\
71.00 \\
-5.00\end{array}$ \\
\hline & $\begin{array}{r}10.42 \\
1.86 \\
-0.04\end{array}$ & $\begin{array}{l}4.43 \\
4.29 \\
4.34\end{array}$ & $\begin{array}{r}10.70 \\
6.48 \\
8.39\end{array}$ & $\begin{array}{l}19.40 \\
20.13 \\
18.83\end{array}$ & $\begin{array}{l}19.19 \\
20.04 \\
20.26\end{array}$ & $\begin{array}{l}26.16 \\
25.62 \\
26.38\end{array}$ & $\begin{array}{l}55.52 \\
58.10 \\
56.59\end{array}$ & $\begin{array}{l}63.13 \\
62.28 \\
63.87\end{array}$ \\
\hline & $\begin{array}{l}0.00 \\
0.00 \\
1.00\end{array}$ & $\begin{array}{l}3.00 \\
3.00 \\
5.00\end{array}$ & $\begin{array}{r}11.00 \\
6.00 \\
5.00\end{array}$ & $\begin{array}{l}21.00 \\
18.00 \\
21.00\end{array}$ & $\begin{array}{l}18.00 \\
16.00 \\
18.00\end{array}$ & $\begin{array}{l}21.00 \\
22.00 \\
25.00\end{array}$ & $\begin{array}{l}60.00 \\
49.00 \\
57.00\end{array}$ & $\begin{array}{l}65.00 \\
56.00 \\
63.00\end{array}$ \\
\hline & $\begin{array}{r}-0.40 \\
0.90 \\
0.80\end{array}$ & $\begin{array}{l}5.30 \\
5.00 \\
4.80\end{array}$ & $\begin{array}{l}12.70 \\
10.90 \\
11.70\end{array}$ & $\begin{array}{l}20.50 \\
18.90 \\
19.70\end{array}$ & $\begin{array}{l}22.40 \\
20.80 \\
20.80\end{array}$ & $\begin{array}{l}25.80 \\
27.50 \\
29.20\end{array}$ & $\begin{array}{l}59.40 \\
54.10 \\
55.90\end{array}$ & $\begin{array}{l}61.80 \\
63.00 \\
60.00\end{array}$ \\
\hline & $\begin{array}{l}2.34 \\
0.00 \\
1.36\end{array}$ & $\begin{array}{l}3.05 \\
3.87 \\
2.76\end{array}$ & $\begin{array}{l}0.00 \\
0.00 \\
0.00\end{array}$ & $\begin{array}{l}20.09 \\
24.87 \\
18.50\end{array}$ & $\begin{array}{l}25.02 \\
24.29 \\
21.83\end{array}$ & $\begin{array}{l}22.56 \\
31.62 \\
26.36\end{array}$ & $\begin{array}{l}56.49 \\
53.38 \\
42.60\end{array}$ & $\begin{array}{l}87.21 \\
80.31 \\
74.85\end{array}$ \\
\hline
\end{tabular}

aorthorhombic $\mathrm{C}_{3} \mathrm{~A}$

${ }^{\mathrm{b}}$ Cubic $\mathrm{C}_{3} \mathrm{~A}$ 
Table 3-2

Cell Averages

(percent of mixture)

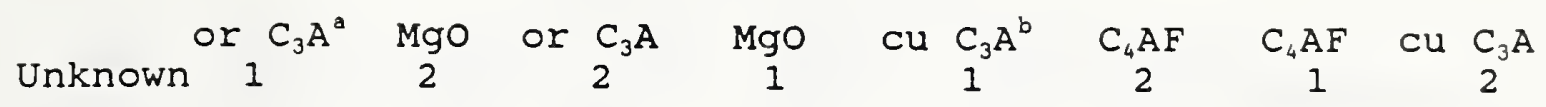

Laboratory

$\begin{array}{rrrrrrrrr}1 & 1.13 & 3.61 & 4.39 & 15.92 & 20.90 & 25.35 & 64.96 & 64.24 \\ 2 & 0.50 & 3.59 & 15.25 & 20.42 & 21.27 & 26.44 & 56.12 & 64.44 \\ 3 & 15.33 & 6.33 & 17.67 & 27.33 & 24.67 & 20.33 & 58.00 & 40.67 \\ 5 & 4.08 & 4.35 & 8.53 & 19.45 & 19.83 & 26.05 & 56.73 & 63.09 \\ 6 & 0.33 & 3.67 & 7.33 & 20.00 & 17.33 & 22.67 & 55.33 & 61.33 \\ 8 & 0.43 & 5.03 & 11.77 & 19.70 & 21.33 & 27.50 & 56.47 & 61.60 \\ 9 & 1.23 & 3.23 & 0.00 & 21.15 & 23.71 & 26.85 & 50.82 & 80.80 \\ & & & & & & & & \\ & 3.29 & 4.26 & 9.28 & 20.57 & 21.29 & 25.03 & 56.92 & 62.31 \\ & 5.47 & 1.10 & 6.14 & 3.42 & 2.42 & 2.59 & 4.21 & 11.70\end{array}$

arthorhombic $\mathrm{C}_{3} \mathrm{~A}$

${ }^{b}$ cubic $\mathrm{C}_{3} \mathrm{~A}$

'overall average of cell averages

${ }^{\mathrm{d}}$ standard deviation of cell averages 


$$
\text { Table 3-3 }
$$

Cell Standard Deviations

(percent of mixture)

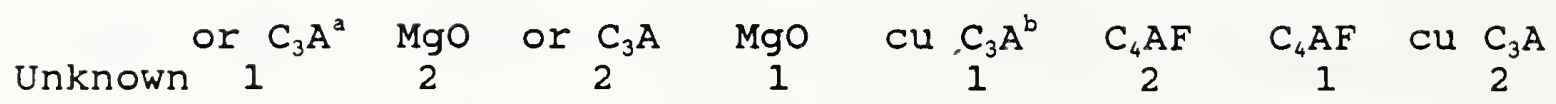

\section{Laboratory}

$\begin{array}{rrrrrrrrr}1 & 1.97 & 0.14 & 3.36 & 0.21 & 0.60 & 1.39 & 2.59 & 1.92 \\ 2 & 2.05 & 0.18 & 2.24 & 1.02 & 1.11 & 3.56 & 2.82 & 2.17 \\ 3 & 13.32 & 4.62 & 21.13 & 3.06 & 5.51 & 13.58 & 6.56 & 40.25 \\ 5 & 5.57 & 0.07 & 2.11 & 0.65 & 0.56 & 0.39 & 1.30 & 0.80 \\ 6 & 0.58 & 1.15 & 3.21 & 1.73 & 1.15 & 2.08 & 5.69 & 4.73 \\ 8 & 0.72 & 0.25 & 0.90 & 0.80 & 0.92 & 1.70 & 2.70 & 1.51 \\ 9 & 1.18 & 0.58 & 0.00 & 3.32 & 1.67 & 4.55 & 7.28 & 6.17 \\ S_{r}{ }^{c} & 5.59 & 1.83 & 8.27 & 1.91 & 2.31 & 5.69 & 4.66 & 15.55\end{array}$

arthorhombic $\mathrm{C}_{3} \mathrm{~A}$

${ }^{\mathrm{b}} \mathrm{cubic} \mathrm{C}_{3} \mathrm{~A}$

${ }^{\circ} r e p e a t a b i l i t y$ standard deviation 
Table 3-4

\section{Between-Laboratory Consistency statistic Values (h-statistic) \\ (percent of mixture)}

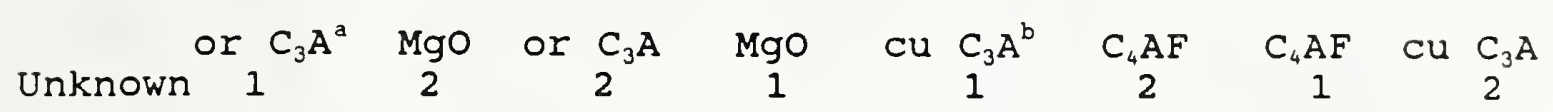

Laboratory

$\begin{array}{rrrrrrrrr}1 & -0.39 & -0.59 & -0.79 & -1.36 & -0.16 & 0.13 & 1.91 & 0.16 \\ 2 & -0.51 & -0.61 & 0.97 & -0.04 & -0.01 & 0.54 & -0.19 & 0.18 \\ 3 & 2.20 & 1.89 & 1.37 & 1.98 & 1.39 & -1.81 & 0.26 & -1.85 \\ 5 & 0.14 & 0.09 & -0.12 & -0.33 & -0.60 & 0.40 & -0.04 & 0.07 \\ 6 & -0.54 & -0.54 & -0.32 & -0.17 & -1.63 & -0.91 & -0.38 & -0.08 \\ 8 & -0.52 & 0.71 & 0.41 & -0.25 & 0.02 & 0.96 & -0.11 & -0.06 \\ 9 & -0.38 & -0.94 & -1.51 & 0.17 & 1.00 & 0.70 & -1.45 & 1.58\end{array}$

Critical 2.05

aorthorhombic $C_{3} A$

${ }^{b}$ cubic $\mathrm{C}_{3} \mathrm{~A}$ 


$$
\begin{gathered}
\text { Table } 3-5 \\
\text { Within-Laboratory Consistency statistic Values } \\
\text { (k-statistic) } \\
\text { (percent of mixture) }
\end{gathered}
$$

$$
\begin{array}{lcccccccc}
\text { or } \mathrm{C}_{3} \mathrm{~A}^{\mathrm{a}} & \text { Mgo } & \text { or } \mathrm{C}_{3} \mathrm{~A} & \text { Mgo } & \mathrm{Cu} \mathrm{C}_{3} \mathrm{~A}^{\mathrm{b}} & \mathrm{C}_{4} \mathrm{AF} & \mathrm{C}_{4} \mathrm{AF} & \mathrm{Cu} & \mathrm{C}_{3} \mathrm{~A}
\end{array}
$$

Laboratory

$\begin{array}{lllllllll}1 & 0.35 & 0.07 & 0.41 & 0.11 & 0.26 & 0.24 & 0.56 & 0.12 \\ 2 & 0.37 & 0.10 & 0.27 & 0.54 & 0.48 & 0.63 & 0.60 & 0.14 \\ 3 & 2.38 & 2.54 & 2.56 & 1.60 & 2.39 & 2.38 & 1.41 & 2.59 \\ 5 & 1.00 & 0.04 & 0.26 & 0.34 & 0.24 & 0.07 & 0.28 & 0.05 \\ 6 & 0.10 & 0.64 & 0.39 & 0.91 & 0.50 & 0.37 & 1.22 & 0.30 \\ 8 & 0.13 & 0.14 & 0.11 & 0.42 & 0.40 & 0.30 & 0.58 & 0.10 \\ 9 & 0.21 & 0.32 & 0.00 & 1.74 & 0.72 & 0.80 & 1.56 & 0.40\end{array}$

Critical 2.02

arthorhombic $\mathrm{C}_{3} \mathrm{~A}$

${ }^{b}$ cubic $\mathrm{C}_{3} \mathrm{~A}$ 
Table 3-6

Summary of Precision Parameters

(percent of mixture)

Phase

orthorhombic $\mathrm{C}_{3} \mathrm{~A}$

Mgo

orthorhombic $\mathrm{C}_{3} \mathrm{~A}$

Mgo

cubic $C_{3} A$

$\mathrm{C}_{4} \mathrm{AF}$

$\mathrm{C}_{4} \mathrm{AF}$

cubic $C_{3} A$
Unknown

\section{1}

2

2

1

1

2

1

$$
s_{r}^{a}
$$

5.59

1.82

8.27

1.91

2.31

5.69

4.66

15.55
$\mathbf{S}_{\mathrm{R}}{ }^{\mathrm{b}}$

7.12

1.84

9.13

3.76

3.07

5.69

5.68

17.26

arepeatability standard deviation

${ }^{b}$ reproducibility standard deviation 


$$
\text { Table 3-7 }
$$

\section{Cell Averages Excluding Laboratory 3 \\ (percent of mixture)}

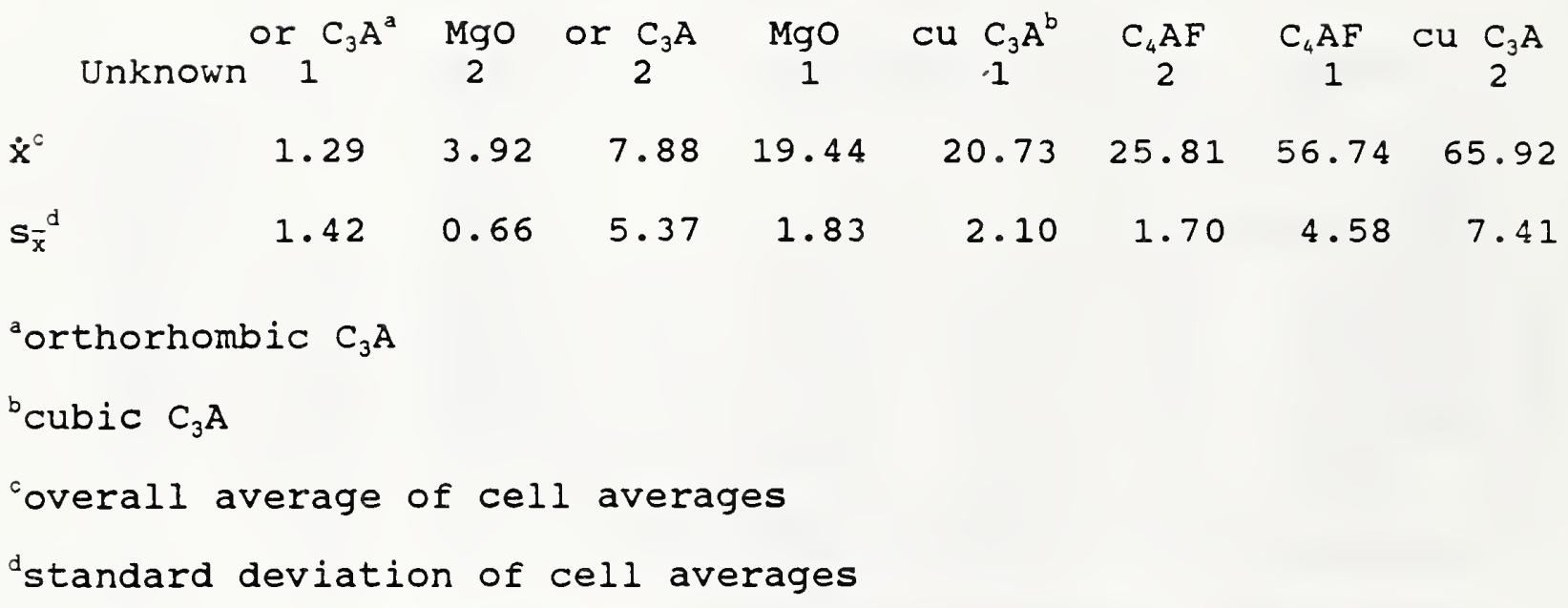




$$
\text { Table 3-8 }
$$

Summary of Precision Parameters Excluding Laboratory 3 (percent of mixture)

Phase

orthorhombic $\mathrm{C}_{3} \mathrm{~A}$

Mgo

orthorhombic $\mathrm{C}_{3} \mathrm{~A}$

Mgo

cubic $\mathrm{C}_{3} \mathrm{~A}$

$\mathrm{C}_{4} \mathrm{AF}$

$\mathrm{C}_{4} \mathrm{AF}$

cubic $\mathrm{C}_{3} \mathrm{~A}$
Unknown

1

2

2

1

1

2

1

2

$$
\mathrm{S}_{\mathrm{r}}^{\mathrm{a}}
$$

2.63

0.55

2.31

1.64

1.07

2.67

4.26

3.46
$S_{R}^{b}$

2.63

0.80

5.69

2.26

2.27

2.76

5.75

7.93

${ }^{a}$ repeatability standard deviation

${ }^{b}$ reproducibility standard deviation 


$$
\text { Table 3-9 }
$$

Linear Regression, Standard Deviation Versus Average

$\begin{array}{ccc}\begin{array}{c}\text { intercept } \\ \text { (percent of mixture) }\end{array} & \text { slope } & \text { Correlation }\left(R^{2}\right) \\ 1.40 & 0.037 & 0.52 \\ 1.86 & 0.075 & 0.56\end{array}$


BIBLIOGRAPHIC DATA

4. TITLE AND SUBTITLE

Cooperative Calibration and Analysis of Cement Clinker Phases

5. $A \cup T H O R(S)$

Leslie Struble; H. Kanare

6. PERFORMING ORGANIZATION (If joint or other than NBS, see instructions)

7. ContracUGrant No.

NATIONAL BUREAU OF STANDARDS

U.S. DEPARTMENT OF COMMERCE

GAITHERSBURG, MD 20899

9. SPONSORINC ORGANIZATION WAME ANC CCMFLETE ADDRESS (Street, City. StOte, ZIP)

8. Type of Report \& Period Covered

10. SUPPLEMENTARY NOTES

Document describes a computer program; SF-185, FIPS Software Summary, is attached.

11. ABSTRACT (A 200-word or less factual summary of most significant information. If document includes o significant bibliogrophy or literoture survey, mention it here)

An interlaboratory calibration and analysis has been carried out by ASTM Task Group C01.23.01 to assess the use of quantitative X-ray diffraction analysis to determine the proporation of phases in portland cement clinker. This interlaboratory test provides an estimate of precision and bias in the quantitative phase analysis of some clinker phases in mixtures prepared using calibrating phases. These estimates of precision and bias will be incorporated in a proposed standard test method on quantitative phase analysis of cement and clinker currently being developed by the task group.

12. KEY WORDS (Six to twelve entries; alphabetical order; capitalize only proper names; and separate key words by semicolons) cement; clinker; interlaboratory calibration; phase analysis; X-ray diffraction

13. AVAILABILITY

Unlimited

X For Official Distribution. Do Not Release to NTIS

$[$ Order From Superintendent of Documents, U.S. Government Printing Office, Washington, D.C. 20402.

Order From National Technical Information Service (NTIS), Springfield, VA. 2216I

14. NO. OF

PRINTED PAGES

15. Price 




$$
\text { I : ins. }
$$

